\title{
Construction of the Principle of Partisanship to the Interests of the Nation on Mineral and Coal Mining Law
}

\author{
Hudriy ah Mundzir \\ State Polytechnic of Malang \\ Malang, Indonesia \\ hudriy ah.mundzir88@gmail.com
}

\author{
Sudarsono \\ Faculty of Law \\ Brawijaya University \\ Malang, Indonesia \\ sudarsono.ast11@gmail.com \\ Istislam \\ Faculty of Law \\ Brawijaya University \\ Malang, Indonesia \\ istislam@ub.ac.id
}

\author{
Rachmad Syafa'at \\ Faculty of Law \\ Brawijaya University \\ Malang, University \\ rachmad.syafaat@ub.ac.id
}

\begin{abstract}
Law politics is a legal policy on regulation that will be put into effect by writing new regulations or replacing the old ones in order to achieve national goals. Law politics on coal, mineral and mining act supporting nation interest may impel different interpretation on prevailing regulation of coal, mineral and mining which in the end result in different implications. Paradigm of land occupation right by the state should be made as new paradigm in land reform. Therefore, there should be re-interpretation on the concept of land occupation by the state which is in line with the development of Coal, Mineral and Mining Act based on the spirit of chapter 33 of 1945 National Law of Indonesia as philosophical foundation for Coal, Mineral and Mining Act supporting nation interest. Partiality aspect for nation interest is the principle of Coal, Mineral and Mining Act. The principle for supporting nation interest requires that in the implementation of the act, either central government or regional government should emphasize on nation interest. It means that nation interest should be prioritized more than those of investors. Still, the state should take the investors' interest into account.
\end{abstract}

Keywords- law politics, coal, mineral and mining act, partiality for nation interest

\section{INTRODUCTION}

Mining have been prominent issues in the developing countries. An economist, Joseph Stiglitz in his book entitled Escaping The Resource Curse stated that crucial loss will fall on countries giving freedom for developed countries to put big number of investment in mining sector. However, it is inevitable that the income from mining process and its output is quite enormous.

Chapter 33 of 1945 National Law of Indonesia functions as the basis of managing mining sector in Indonesia. It is used as the basis to construct an economic justice but not ecology one. The effect of mining activities is not only environmental damage but also social unrest. The example is the escalation of conflict between mining companies and the people, the changing of agrarian culture into mining one and the damage and pollution on environment surrounding the mines. Chapter 33 of 1945 National Law of Indonesia is law politics or principle policy determining the goal of law enforcement in natural resources management and ensuring democracy in natural resources management and future economy.

Law no 11 of 1967 on Principle Requirements of Mining does not put down explicitly the prevention and recovery for area surrounding mines. Government regulation no 75 of 2001 on Second Amendment of Government regulation no 23 of 2009 on The Imple mentation of Law no 11 of 1967 on Princip le Require ments of Mining gives little explanation for that matter. It regulates the reclamation as surance cost and environmental management and supervision activities (Chapter 41 verse 1e), supervision on mining environmental protection activities including area reclamation after mining and conservation and improvement of added-value (chapter 64 verse $3 \mathrm{~d}$ and $3 \mathrm{e}$ ) and other aspect such as regional government's role in environmental supervision and reclamation (chapter 67). However, the regulation doesn't give details on that matter.

National Law no 4 of 2009 on coal, mineral and mining gives juridical basis on mining management related to its environmental aspects and it contains also chapter on mining independency of Indonesia. Concerning environmental aspects, the law takes several environmental problems into account although it misses many principle issues of environment. Mining activities in Indonesia are conducted using contract systems and pluralistic mining permit system. There are several mining contracts and permits system which are based on Law no 11 of 1967 on Principle Requirements of Mining and some others are based on Law no 4 of 2009 on Coal, Mineral and Mining Act. Mineral and coals are strategic non renewable natural resources occupied by the state and they are vital for public necessities and play crucial role for national economy. Therefore, their management should be able to maximize public prosperity.

Based on chapter 33 verses (2) and (3) of Indonesian National Constitution of 1945, the state as the owner of management right should focus on nation interest. Furthermore, partiality ideology for nation interest is stated 
clearly in chapter 2 of Mineral acts stating that "mineral an/or coal mining are managed based on the principle of: 1 . Profitability, fairness and balance; 2) partiality for nation interest; 3) participatory, transparency and accountability; 4) sustainability and environment conception". Though partiality principle for nation state has been written in Coal, Mineral and Mining Act, there is no explicit explanation of meaning and substance of partiality principle for nation interest. Therefore, the meaning and substance of partiality principle for nation interest are still left unclear. The weakness of Coal, Mineral and Mining Act is that it has no umbrella act giving explicit elaboration on state partiality for nation interest. In preamble of Coal, Mineral and Mining Act, there is no umbre lla act to supervise the implementation of the act.

Partiality principle for nation interest is stated in prevailing in order to achieve nation goals. The aim of Coal, Mineral and Mining Act is to give concrete added value for improvement of national economy and sustainable national development. On chapter 5 verse (1) and (2) of Regulation of Minister of Energy and Mineral Resources of Indonesia no 1 of 2014 on The Value Addition of Mineral through Management and Purification Activity, it is stated that there must be processing and purification activity of mining product before being exported in order to create economic, social and cultural profit. The chapter also aims at giving more value on mining product that is exported in the form of raw materials that make their value low.

Coal, Mineral and Mining Act is supported by SDG (Sustainable Development Goals). SDG was declared by United Nation at the end of September 2015 in New York and it is valid from January 2016 up to December 2030. There are 193 me mber countries of United Nation committed to implement SDG and one of them is Indonesia. To achieve SDG, there must be active participation from all related stakeholders including companies and other related institution. In Indonesia, SDG was declared in the form of President Regulation no 59 of 2017 on The Implementation of Target Achievement of Sustainable Development (SDG). To disseminate the regulation, Corporate Forum for Community Development (CFCD) together with the government initiates the so called SDG Corporate Summit.

Those afore-mentioned statements are in line with the fiftieth goal of Sustainable Development Goals which is to protect, renew, and encourage the use of sustainable land ecosystem, to manage forest, to prevent deforestation, to stop and recover land degradation and to stop the damage of biodiversity. The participation of Indonesia in SDG implementation is the manifestation of state partiality to higher interest in order to create ecology fairness. This article discusses on how construction of partiality principle for nation interest is manifested in Coal, Mineral and Mining Act in order to create environmental fairness.

\section{SIGNIFICANCE AND EASE OF USE}

\section{A. Theoretical Significance}

Theoretically, it is expected that this paper might be used as a review on base principle contained in prevailing regulation, as an enrichment of law study in order to build solid scientific argument as a search engine to find weaknesses in law study especially those related to mining law. The impact of scientific aspect of this paper is that there are several findings showing strength and weaknesses that should be corrected to make mining regulation perfect.

\section{B. Practical significance}

Practically, this paper may give contribution to our knowledge especially aspects related to state partiality for nation interest in mining management. For regional government, it is expected that this paper might give information on regional government's authority in mining management to improve people prosperity and minimize environmental damage caused by mining industries. For central government, this paper is expected to give analysis and law argumentation in order to give contribution for law enforcement resulting in fair implementation of law to create fair and conducive working atmosphere and to ensure law certainty for businessmen. Therefore, this paper might give contribution in the form of scientific review of law that is beneficial for economic recovery in Indonesia.

\section{DISCUSSION}

\section{A. Law Construction}

The discussion of this paper is in the form of overview on definition of construction in law study. Basically, law construction is similar to analogy but several law constructions are variations from the analogy namely law refinement and Argumentu a Contrario construction.

\section{Law Construction /Law Composition (Rechtscontructie)}

\section{Analogy construction (argumentum per analogiam)}

Analogy is construction process by finding retio legis (genus) of certain kind of law and then applying them to other aspects which are not regulated by the law. In analogy, the judges put certain problems into a context of regulation of certain law that is actually not intended for that problems. It is because there some similarity with other problem or facts that might be solved using existing regulation. Based on the conception, the judges uses existing legislation for existing problem. In other words, the implementation of certain regulation for certain circumstances is basically the same as others regulated by certain law with different form of law.

Law implementation using analogy might be conducted for cases of civil law. Analogy cannot be used for criminal law because it violates the principle of criminal law that "no crime without pre determined legislation" (nullum crimen sine lege). In criminal law, the use of analogy might result in new crime.

Therefore by using analogy, law expert might put certain problem into context of existing legislation which is not actually intended for that.

\section{Construction of Law Refinement}

A law expert might find that existing legislation that is supposed to be used for certain problem doesn't work.

Law refinement might be employed if the application of prevailing legislation results in crucial injustice problems. Therefore, the legislation should not be applied to other problem for fairness. This kind of construction is the reverse form of analogy construction. In one side, analogy principle means expanding the scope of existing regulation and on the 
other side, Law Refinement limits the scope of related legislation (restrictive in nature).

\section{Argumentum a Contrario}

In this circumstances, the judge applies certain acts similar to analogy context by applying a certain legislation on problem which is not intended for that. The difference is hat analogy by the judge will result in positive conclusion; meaning that he applies a legis lation for problem at hand. For Argumentum A Contrario construction, the judge comes to negative conclusion; meaning that it is impossible for him to apply existing legislation for problem at hand. Reviews from law experts on law interpretation results in various theories, methods or different interpretation. It is due to the difference of scale and categories used.

The followings are types of interpretation methods and law construction used are:

1. Grammatical interpretation method. It is conducted by interpreting the law based on the meaning or words stated on the law. Judges are required to assess the meaning of words based on their daily usage among our people. The requirement of grammatical interpretation is logical. Therefore, the method is also called objective method.

2. Systematic method of interpretation. The legislations are interpreted by relating them to other legis lations or whole system of law. The rationale for this method of interpretation is that essentially a certain legislation is part of prevailing law system. Therefore, there is no legislation which is apart from others. Logical consequences of this concept is that the interpretation of certain legislation should not be out of context of law system. Then, this systematic system is also known as logical interpretation.

3. Historical method of interpretation. This type of interpretation is conducted by reviewing the background history of composing or constructing related legislation. In law study, historical interpretation is divided into two. Those are

a. Interpretation based on the history of declaration of certain legislation (Wethistoirsche interpretatie). The legislations are interpreted by studying their development since their declaration, their objective or the explanation from the writer of legislation. This type of interpretation is also known as subjective interpretation because it makes use of subjective point of view of the writer. Therefore, interpretation method of law based on their history is the opposite of grammatical interpretation which is called objective interpretation.

b. Interpretation based on law history (Rechts Historische Interpretatie) is a way of how to interpret the legislation based on the context of law history. The rationale underlying this method of interpretation is that each law is always the form of fulfilment of social need. Each legislation might be considered as a way to keep up with the development in society. Therefore, the meaning and intention of law can be recognized. It must be understood by all institutions implementing the laws.

4. Theological or sociological Method of Interpretation. This method of interpretation is intended to find out the meaning legislation based on the need of society. This type of interpretation is implemented to prevailing legislations which are not inline with the development in society. Therefore, there must be new interpretation for existing legislation making them suitable with current occurrences, relations, needs and conditions. It is done without considering whether it is already familiar or not upon their declaration. In short. Theological or sociological method of interpretation is an effort to keep up with current relation and social context in our society because in fact, the legislation is not relevant to solve problems.

5. Anticipative or futuristic interpretation. Upon this method, the legislation is interpreted by elaborating the requirements of related legislation based on laws that are not declared yet. It is usually in the form of legislation draft.

6. Evolutive-dynamic interpretation occurs when in their verdict, judges gives determining meaning (a breakthrough) for prevailing legislations after (declaration) certain legislations.

7. Restrictive and extensive interpretation. Based on its formulation, law interpretation is divided into restrictive and extensive interpretation. Restrictive interpretation occurs when a word is interpreted based on its meaning in dictionary or even narrower meaning than what is stated in dictionary or colloquial meaning. The extensive interpretation is when larger meaning is given to a word than what is stated in dictionary or its colloquial meaning.

8. Analogy construction method. It is a law formulation method by inserting certain problem into the context of legislation which is actually not intender for that problem.

9. Argumentum a contrario construction method is a method to give opposite meaning to concrete occurrences and it is different with what is stated in legislation. Then, we come to conclusion that problem at hand is beyond the scope of related legislation.

10. Construction method of law refinement is e method to take problems at hand out from related legislation.

\section{B. Meaning of Partiality Principle for Nation Interest}

There must be principle of law for system of law functioning as base principle and directions to formulate certain legislation. Thus, as a citizen we should understand this law principle prevailing in Indonesia. Concerning the language used, there are three meaning of principle. Those are 1) basis/foundation, 2) underlying truth for stating opinion and thought, 3) objectives underlying certain group of people. Based on the three meaning, we come to conclusion that principle is foundation of truth that is used as bas is for stating opinion and thought.

Law principle is not law itself but norms of law will not be able to comprehend without the principle. It connects norms and value. Paul Scholten states that law study should find out principle of law in the context of positive law. Therefore, we are able to understand the objective of state. As public norm, there are several substances/imperatives that must be used as principle of law morality. Firstly, Law should belong to everyone to help them to be good person. 
Secondly, the law should not be the monopoly of certain people or group (people interest should be accommodated equally). Third, the law should be public guidance functioning as public space in which truth, justice and fairness are maintained and prioritized. The fourth, as public guidance, law should be based and able to maintain public values. Fifth, norm of law should be agreed upon freely based on communication between all groups of people. Sixthly, those in charge of public guidance should obey public values and norms attached to their title. Seventh, betrayal for the duty to maintain public guidance is taken as serious contempt for public interest; and the last, to prevent betrayal, moral habit in law should be developed.

Chapter 2 of L aw no 4 of 2009 on Coal, Mineral and Mining Act contains law principles of Coal and mineral mining. There are seven principles of Coal, Mineral and Mining Act. They are profitability, fairness and balance; $b$. Partiality on nation interest; c. Participation, transparency and accountability and d. Sustainability and environmentally insight. Those principles are then elaborated as follows. 1. Profitability. This principle requires that coal, mineral and natural resources should be able to give profit for people. It is in line with concept proposed by Jeremy Bentham. The law should be useful and able to serve public utility. The utility concept developed by Jeremy Bentham is intended to elaborate the concept of happiness and prosperity. Something that is able to create extra happiness is a good thing. On the other hand, something creating pain is bad. Therefore, government acts should focus on improving prosperity of as many people as possible (the greatest happiness principle). 2 . Fairness. It requires that the in managing coal, mineral and natural resources, Coal, Mineral and Mining Act should ensure that people have same right and profit. People may get right to manage and explore mineral and coal and they are obliged to preserve the surrounding nature. So far, government gives special permits only for big scale companies in exploring mineral and coals; 3 . Balance. It is law principle requiring that there must be an equal and balance position between permit giver and holder in managing coal and mineral mining. Permit giver may demand their right to permit holder in the form of IPR, IUP or IUPK. Furthermore, the permit holder may also demand the permit giver to fulfil their obligation such as giving guidance and supervision to permit holder. This is the essence of balance between duty and right. 4. Partiality for nation interest. It is princip le containing in Coal, Mineral and Mining Act that governments, either central or regional, should give priority on higher interest of nation. It means that nation interest should be put after that of investors. However, investor interest should be taken into account also. 5. Participation. This law principle containing in Coal, Mineral and Mining Act requires that people around mining industries should take part in mining activities. It means that people around mining site can be either owner, distributor of mining product or work at mining industries; 6 . Transparency. This principle of law requires that the implementation of mineral and mining activities should be transparent. I means that every information should be made clearly and disseminated to all people such as stages of mining activities, need of workers and others; 7. Accountability. This principle of law requires that mineral and coal mining should be accountable to people as stakeholder by taking fairness and properness aspect into account. It is closely related to rights obtained by either central or regional government from mineral or coal mining activities. For instance, companies having IUPK should give $1 \%$ of their profit to regional government and it should be accounted for people's representatives at regional, or provincial level; and 8. Sustainability and environmentallyinsight. The principle of law requires to integrate economy, environment and social culture dimension in coal and mineral mining activities to reach people's prosperity at present or future.

Principle of partiality for nation interest in Coal, Mineral and Mining Act requires that regional or central government should give more priority on higher nation interest. Law no 4 of 2009 on Coal and Mineral Mining doesn't state explicitly the meaning of this principle. It means that nation interest should be put after investors' interest. Dictionary of Indonesian Language stated that the meaning of partiality is to take side on people in order to create social prosperity. This partiality by government aims at improving social prosperity on the part of the people. The phrase "to improve social prosperity" implies that existing social prosperity should be increased. In addition, the meaning of social prosperity is safe, prosperous condition for people.

Then, based on the above explanation we come to conclusion that nation interest is put in the form of government's effort to reach the objectives of Law No 4 of 2009 on Coal and Mineral Mining to uphold people's prosperity whish is safe and prosperous.

\section{The manifestation of Partiality Principle for Nation Interest in Supervising Mining Activities}

In accordance with the aim of Coal, Mineral and Mining Act, government represented by Mining Inspectorate is required to supervise mining business activities. The objects of supervision are: (1) mining technical aspects; (2) Coal, Mineral and Natural Resources conservation; (3) Safety and Healthy aspects at work in Mining; (4) Safety of Mining Operation; and (5) management of Environment, Reclamation and post-mining activities. Based on chapter 140 verse 1 of Law no 4 of 2009, Ministry of Energy and Resources is responsible for supervising mineral and coal mining industries and the supervision authority is given to regional government. The supervision covers admin istration/management aspects; operational procedures; competence of staff and the implementation of business mining program. Based on the authority they have, the minister, governor and head of regional government should supervise the implementation of mining activities of companies having IUP, IPR or IUPK (chapter 140 verse 3).

The supervision is conducted by evaluating program report and the implementation of mining activities of companies with mining permit (IUP, IPR and IUPK). The supervision of the implementation of mining business activities covers the following areas; namely Supervision of Technical Aspects of Mineral and Coal Mining which include: (a) IUP or exploration of IUPK consisting of the implementation of exploration technique and procedures of calculating natural resources and its reserve; b) Production Operation of IUP or IUPK which consists of planning and implementation of construction including mining equipment calibration (commissioning); planning and implementation of mining; planning and implementation of processing and purifying activities; and planning and implementation of trans portation and marketing. 
Marketing supervision includes: (a) realization of production and selling including quality and quantity of coal and mineral price; (b) obligation to fulfil domestic need for coal and mineral; (c) plans and their realization of coal and mineral selling contract; (d) selling cost; (e) planning and realization of non tax government income; (f) cost of processing and purifying mineral and/or coal. Financial supervision includes: budget plans, budget realization; investment realization and the fulfilment of payment.

Supervision of data of mineral and coal covers areas of exp loration activities, ad min is tration, proces sing, structuring, filing, maintaining and diminishing data and/or information. Conservation of excavation materials is an effort to process the materials by taking all needs, development of technology, economy, social culture, politics factors as well as other factors into account. The conservation is based on principle of optimization, economization, sustainability and profitability for people. It also aims at making use of excavation material wisely and preventing the waste in order to create people prosperity and sustainable development. The conservation is conducted by (1) mining and processing recovery; (2) processing and/or making use of marginal reserves; (3) processing and/or making use of low quality coal and low-content mineral; (4) processing and/or making use of by-product minerals; (5) composing data of natural resources and mineral and coal reserves and (6) composing data and processing residue of processing and purifying activities. Then, the supervision of healthy and safety procedures at mining is done to ensure a system of proper safety and healthy procedure involving management and workers. It also ensures integrated condition and working environment in order to prevent and reduce accidents at work and to create efficient, safe and productive workplace. Therefore, there must be a management system of Safety, Healthy and Security procedures. Decree of Work Affairs Ministry no Per.05/1996 stated that the safety procedures is part of whole management system covering organization structure, process and resources needed to develop, implement, achieve, review and maintain policy of safety and healthy procedures at workplace. It aims at minimizing and controlling risk to create safe, efficient and productive workplace.

In general, the principle of mining management has tried to manifest the objectives of Chapter 33 verses 3 and 4 of Indonesian Constitution of 1945. It is put into principles of mining management which is planned and integrating economy, environment and social cultural aspects in order to create prosperity at present and future. Based on the principle, the objectives of mining management as stated in verse 3 of Coal, Mineral and Mining Act are as follows:

a. To ensure the effectiveness of implementation and controlling of mining activities which are profitable, independent and competitive.

b. To ensure sustainable vale of coal and mineral mining based on environment-insight.

c. To ensure the availability of mineral and coal as raw material and/or energy resources for domestic needs.

d. To support and develop national capability to compete at national, regional and international level.

e. To improve people income and create job vacancies for prosperity of people. f. To ensure law certainty in coal, mineral mining activities.

The governments plays several roles such as:

a. As provider of people's prosperity

It relates to welfare state, in which government is required to determine minimal standard on people welfare and types of social insurance. The determined standards should be benchmark to assess welfare of people.

\section{b. As regulator}

As constitutional state, Indonesia should be able to play its role as regulator. Therefore, all policies should be stated in regulations.

\section{c. As entrepreneur}

This function is dynamic in nature and urgently needed. Thus, the state might function as entrepreneur by building state-owned or private-owned corporation. As entrepreneur, permit giving to private industries should uphold people welfare. The function of state as entrepreneur must be put into regulation that is in line with scope and level of authority.

\section{d. As umpire}

In doing the function, the state must obey all prevailing regulations. They should formulate standards prioritizing on fairness aspect on economy sector. It is not easy to supervise this function because there will be "conflict of interest" on the part of the state. Thus, fairness standard should be referred in conducting supervision.

From the above functions, the most essential one is regulator function. Therefore, every legislation product should reflects provider, entrepreneur and umpire function on the part of the state.

Concerning the function of state in economy sector containing in Coal, Mineral and Mining Act, then in general the function has been elaborated as follows:

"....mining business should adapt themselves with the change of strategic environment either at national or international level. Main challenges faced by government concerning mining sectors are the effect of globalization encouraging democratization, regional autonomy, human rights, environment, development of information technology, intellectual property right and improvement of private and people participation".

The essence of explanation of Coal, Mineral and Mining Act is on the state function as regulator. Therefore, government should be able to put itself as regulator amidst dynamics and phenomenon of mining industries and resistance of their stakeholder.

\section{REFERENCES}

[1] Dr. Otong Rosadi, SH., Mhum, Quo Vadis Hukum, Ekologi dan Keadilan Sosial dalam Perenungan Pemikiran (Filsafat) Hukum, Thafa Media, Yogyakarta

[2] Trihastuti, Nanik, Hukum Kontrak Karya Pola Kerjasama Pengusahaan Pertambangan Indonesia, (Malang: Setara Press (Kelompok Penerbit Intrans), 2013

[3] Bambang Santoso, Relevansi Pemikiran Teori Robert B. Seidman tentang "The Law of Non Transferability of The Law" dengan Upaya 
Pembangunan Hukum Nasional Indonesia, Jurnal Yustisia Nomor 70 Januari-Aril 2007, hlm. 7

Franky Butar-Butar, Penegakan Hukum Lingkungan di Bidang Pertambangan, Jurnal Yuridika Volume 25 Nomor 2, Mei-Agustus 2010

[4] Gie, Kwik Kian, Siasat Liberalisasi Ekonomi, Reform review (Jurnal Untuk Kajian dan Pemetaan Krisis), Volume II Nomor 1 April -Juni 2008,
[5] Indah Dwi Qurbani yang berjudul "Politik Hukum Pengelolaan Minyak dan Gas Bumi" yang diterbitkan di Jurnal arena Hukum Volume 6, Nomor 2, Agustus 2012

[6] Hudriyah Mundzir, dkk, Analisis Yuridis Undang-Undang Nomor 4 Tahun 2009 Tentang Mineral dan Batubara jo. Pp Nomor 1 Tahun 2014 Mengenai Pelarangan Ekspor Hasil Tambang Mineral Mentah dibiayai dengan Dana DIPA Nomor: SP_DIPA023.04.2.576811/2014 tanggal 5 Desember 2013 Politeknik Negeri Malang dengan Surat Perjanjian Nomor: 6067/PL.2.1/HK/2014. 